\title{
Nematophycus Storriei, nov. sp.
}

\author{
C. A. BARBER, M.A.,
}

Superintendent of Agriculture for the Leeward Islands ; late Scholar of Christ's College, and Demonstrator of Botany, in the University of Cambridge.

\section{With Plates XIX and XX.}

THE anatomical structure and mode of occurrence of primaeval plants cannot but be of great interest to the student of nature. For many years past the existence, in the Carboniferous age, of gigantic club-mosses and other fernallies has excited our wonder; and we are now led to believe that, in the older rocks of the Devonian and Silurian periods, forms existed whose structure points to a close connection with the algae.

Pieces of these fossil plants, of great size, occurring in the lower Devonian of Canada, were originally described by Sir William Dawson under the name of Prototaxites ${ }^{1}$. This name was generally found unsuitable, and Mr. Carruthers, in a wellillustrated paper published in the Monthly Microscopic Journal of October, 1872 , pointed out the algal affinities of the plant, and changed the generic name to the more applicable one of Nematophycus.

It may be noted, in passing, as a remarkable fact, that the present genus and Pachytheca, long suspected to be parts of the same plant, and occurring, for the most part, in the same beds, form, with Chara and a few unicellular organisms, the

\footnotetext{
${ }^{1}$ Geol. Surv. Can., Fossil Plants, I87r.
} 


\section{Barber.-On Nematophycus Storriei, nov. sp.}

sole representatives of the algae which exhibit structure in the fossil state.

The protracted discussion between Sir William Dawson, on the one hand, and $\mathrm{Mr}$. Carruthers on the other ${ }^{1}$, together with the careful anatomical description by Professor Penhallow ${ }^{2}$, has presented us with a clear impression concerning the nature and affinities of Nematophycus, as far as these can be judged in the total absence of reproductive organs.

Thus far, the only detailed descriptions have related to one plant-Nematophycus Logani; and, consequently, the full treatment of any new species will add considerably to our conceptions of this remarkable genus.

While examining the slides of Pachytheca in the possession of Mr. Storrie at Cardiff, specimens of Nematophycus were placed before me, which appeared to me to differ in several important points from the published descriptions of $N$. Logani, and a subsequent examination of a specimen of the latter fossil, kindly communicated to me by Sir William Dawson, confirmed me in this impression. The description of this new species forms the subject of the present paper; and, as a tribute to the energy displayed by Mr. Storrie in collecting the specimens, and the skill with which he has prepared the microscopic sections, both of this fossil and of Pachytheca, I propose to call the Cardiff fossil Nematophycus Storriei.

The locality and horizon from which the Cardiff specimens were collected have been detailed in a former paper on the structure of Pachytheca ${ }^{3}$. The small pieces of Nematophycus are found in the same layers as the specimens of Pachytheca, and occur in the Tymawr quarry near Cardiff, in rocks of about Wenlock age.

1 Literature quoted by Penhallow :-Journ. Geol. Soc. xv. 484; A ug. 188I, 482 ; May 1882, 104; Geol. Surv. Can. 1863, 401 ; I871, I6; 1882, II. 107; Can. Nat. (New Ser.) vii. I 73 ; Ann. and Mag. Nat. Hist. 5, ix. 59; M. Micr. Journ. viii. I60; x. 66,208 ; xi. 83 ; Quart. Journ. Micr. Sc. xiii. 3 I 3 ; Amer. Nat. v. 245, I 85 ; see also Dawson Geol. Hist. of Plts.

${ }^{2}$ On Nematophyton and allied forms, \&c., Trans. Roy. Soc. of Canada, VI. iv. I 888 .

3 Annals of Botany, v. $145, \mathrm{I} 89 \mathrm{I}$. 
Barber.-On Nematophycus Storviei, nov.sp. $33 \mathrm{I}$

It may be well, before proceeding, to give a summary of the characters on which the genus Nematophycus was founded, after which it will be easier to form an intelligible idea of the structural details peculiar to $N$. Storriei. The species already instituted are $N$. Logani, Dn.; Hicksii, Eth. ${ }^{1}$; laxum, Pen. ${ }^{2}$; but from the two latter we can learn little at present. $N$. laxum is described from a few small pieces of fossil wood found associated with $N$. Logani, while the state of preservation in $N$. Hicksii is anything but what could be desired. These two 'species' will, however, be referred to in the sequel.

For the present, then, I shall confine myself to a reference to $N$. Logani, because this is the only species of which any clear idea or good illustrations exist.

\section{Nematophycus Logani.}

Nematophycus Logani occurs in the form of fragments, frequently of large size, in the Lower Devonian rocks of Canada. The substance of the plant, as its name implies, consists of a number of thread-like cells. These appear as undivided, elongated, sinuous tubes, with the rarest exceptions entirely separate from one another. The tissue therefore forms a mass of interwoven filaments, recalling more or less vividly the structure of Codium and other non-septate Siphoneae (Fig. I).

In this latter plant the separate cells arise independently, as in the tissue of a fungus, and may be considered as separate plants. But it is not altogether safe to conclude that Nematophycus belongs to this class of plants, because such 'hyphal tissue' forms a large proportion of the older thallus of Fucus and other Phaeophyceae.

The tubes of $N$. Logani, moreover, may be readily divided into two classes, according to their diameter and the thickness of their walls. Between the larger cells, visible under the lowest power, may be detected, on further examination, a dense network of much narrower tubes (Figs. 2, 3).

1 Quart. Journ. Geol. Soc. of London, I88r.

2 Penhallow, Trans. Roy. Soc. Can., VI. iv. I 888. 


\section{Barber.-On Nematophycus Storviei, nov. sp.}

The presence of these two well-marked kinds of cells is characteristic of Nematophycus Logani; and, as will be seen in the sequel, this forms a separating character between this species and $N$. Storriei.

The transverse section of Nematophycus Logani is characterised by the presence of a number of more or less radially arranged spaces. These appear like clefts in the tissue, of fairly constant width, but varying considerably in their radial extension (Fig. 4).

At first sight they appear to be regions where the tissues have decayed, but a closer examination occasionally reveals the branching and subdivision of a larger tube-leading Professor Penhallow to suggest that these spaces are the points of junction between the otherwise distinct larger and smaller tubes.

There appears, under a low power, in the transverse section, to be a series of well-marked concentric rings (Fig. 4). This is caused by the considerably diminished diameter of the larger tubes in these zones. It is natural, from our knowledge of exogenous stems, that the term 'rings of growth' should be applied to these. There is always a gradual change in the diameter of the tubes in these regions, as opposed to the sudden widening of the spring-wood in dicotyledonous stems. Occasionally a double ring is met with, such as usually accompanies the formation of new shoots during the summer in plants with secondary thickening.

Beyond these peculiarities of structure, the whole trunk may be said to be fairly homogeneous. No distinction seems to have been noted between the structure of the central portions of the stem and that of the peripheral parts, such as would appear if there were a distinct bark ${ }^{1}$.

The tissues described so far seem to belong to an alga of large size with general siphoneoid characters.

No traces of leaves or roots seem to have been discovered. Possibly the thallus was not flattened into 'leaves,' although it is hardly probable that the plant was devoid of roots or hapteres.

The anatomy thus indicated is derived from a careful

\footnotetext{
1 Penhallow, loc. cit., p. $4^{2}$.
} 
examination of the specimens and a perusal of the descriptions of Professor Penhallow and Mr. Carruthers. The plates illustrating the former paper are unfortunately of little use, and those drawn by Mr. Carruthers in the Monthly Microscopic Journal, October I, 1872, form at present the only reliable illustrations of this fossil. I have, accordingly, prepared a few figures exhibiting the main points of structure under discussion, so that the difference between the present plant and $N$. Storriei will be rendered more evident.

The summary of the structure of $N$. Logani given above represents the present state of our knowledge on the subject. Although, in the main, I am perfectly convinced of the correctness of Professor Penhallow's description, there are several points on which I am not so well satisfied, and which I shall discuss in the sequel. I am not quite content, for instance, to regard the spaces as functionally branching depôts for the junction of larger and smaller tubes. No single instance have I seen of a 'large tube ' being connected with a 'small tube.' Both the larger tubes and the smaller undoubtedly branch, and the smaller tubes appear to be divided by transverse walls.

\section{Nematophycus StorRiei, nov. sp.}

The pieces of this fossil, on which the present description is based, were all obtained by Mr. Storrie from the Tymawr quarry, near Cardiff, and prepared for the microscope by the same gentleman.

The beds in that quarry, as already noted, are considered by Professor Sollas to belong to Wenlock ${ }^{1}$ age $^{2}$. The fragments of fossilized wood occur as small, broken, waterworn bits, imbedded in a crumbling argillaceous matrix, with accompanying specimens of Pachytheca. The stems of N. Logani, on the other hand, are described as occurring in great blocks much resembling the massive trunks of Carboniferous age.

1 Annals of Bot., v. 146.

${ }^{2}$ Sollas, on the Silurian District of Rhymney and Pen-y-lan, Cardiff : Quart. Journ. Geol. Soc., xxxv. p. 475,1879 . 


\section{Barber. On Nematophycus Storriei, nov. sp.}

The microscopic examination of the present species has been rendered difficult on account of the smallness of the area of the sections; but the structure is preserved in a most remarkable manner, rendering the slides much more amenable to photographic methods than those of $N$. Logani. In general character the plant consisted of a number of separate interlacing tubes, undivided, usually unbranched, but of varying size. The tubes cannot be sharply divided into large and small, as is the case in $N$. Logani, but the spaces between the larger tubes contain those with thinner walls and of smaller diameter (Figs. 5, 6, 7, 8).

Scattered through the tissue are 'spaces,' as in $N$. Logani. But the spaces in $N$. Storriei are more or less isodiametrical in transverse section, as contrasted with the radiating spaces of $N$. Logani. From the smallness of the specimens I have not succeeded in satisfying myself regarding the existence of 'rings of growth.'

Having regard to the characters enumerated thus far, we notice in $N$. Logani all the appearances of a secondary tissue. The regularity of the larger tubes, the growth-rings and the radiating spaces at right angles to them, might, indeed, appear to indicate the secondary tissue of a form having the scattered spaces and varying loosely arranged tubes of $N$. Storriei. With regard to the periphery, it is exceedingly doubtful whether it is represented among the specimens examined. In one or two cases, however, an indentation of the surface is accompanied by a complete change in the direction and arrangement of the tubes-a fact which would seem to indicate that the indentation was caused by a surface-wound during the life of the plant. If such be the case, it may be confidently affirmed that there is no bark or definite external layer in $N$. Storriei.

Such are the main characters of Nematophycus Storriei. In the matter of branching, we find, as pointed out by Professor Penhallow in N. Logani, that the spaces are the regions where this is most evident. In fact, while it requires great care to detect such branching of the large tubes in the latter fossil, in 
Barber. - On Nematophycus Storriei, nov. sp. 335

the present case it is a marked and striking character. As will be seen in the transverse, and more especially in the longitudinal sections figured (Figs. 9 and 10 ), there is a perfect network of tissue in some of the spaces.

But branching occurs elsewhere. It is not confined to the spaces, but may be met with in the ordinary tissues far from any space, as will be seen from Fig. II. It is, however, rare in such positions. In passing, it is certainly worthy of note that, although the branching is so excessive in these spaces, yet the small-tube net-work of $N$. Logani is absent in the present species, although the structural details are well preserved. Therefore, Professor Penhallow's suggestion, that the spaces are functionally regions of union between the larger and smaller tubes, must be regarded with caution. One of the peculiarities of the slides of Nematophycus Storriei, not noticeable in Sir William Dawson's slides, is the presence of numerous filamentous bodies, of short length and great tenuity, appearing to have their origin in the walls of the larger tubes (Figs. I 2 and 13). The presence of these bodies is always accompanied by an apparent disintegration of the tubes. Occasionally they form a network, and forcibly call to mind the hyphae of a minute fungus parasitic on the walls of the tissue. The resemblance is emphasized by the presence of spherical punctate bodies, much resembling masses of spores (Fig. I4), which occur in the cavities of the tubes. Occasionally a tube is seen to arise from such a mass (Figs. 7 and 14). The appearances alluded to seem to be sufficiently striking to be figured, although my present feeling is against their plant-nature. It seems possible that they may belong to some such mineral form as the 'trichites' seen in certain rock-sections. I have not, however, met with them in the sections of Pachytheca, although the lithological character of the two fossils may be considered identical.

As already remarked, no single case has come to my knowledge of the connection of the larger with the smaller tubes in Nematophycus Logani. The nearest approach to such a union 


\section{Barber.-On Nematophycus Storriei, nov. sp.}

is seen in Fig. 15. The large tube, at this point, appears to give rise to branches of nearly the same diameter as the small tubes. At a short distance from this point the smaller tubes are branching considerably; and, from a careful examination of the sections, I find numerous cases of small tubes branching in the spaces (Fig. I6). The branches are, however, all uniform in size; and where a large tube divides, its branches have much the character of the similar branches of $N$. Storrici.

The smaller tubes appear to me to be segmented. All search after such dividing walls in the larger tubes has been fruitless, and the many delusive appearances, in examining a fossil section under high powers, has made it difficult to be certain regarding this point.

I have succeeded, however, in observing appearances in isolated tubes which have convinced me that the smaller tubes are really divided by transverse walls (Fig. 16). The relation of large tubes to small tubes remains a mystery, and the introduction of transverse walls into the smaller tubes renders the classification of the fossil a matter of difficulty.

Such are the results of my examination of slides prepared from a single specimen forwarded from Canada. An exhaustive study of the numerous slides in Sir William Dawson's collection would be necessary before the correctness of these observations could be determined.

With regard to the function of the radiating spaces of $N$. Logani, I have a certain amount of difficulty in accepting Professor Penhallow's suggestion of 'branching depôts.' I do not think, at any rate from the illustrations appealed to, that the connection between large and small tubes has been 'proved '.' I have shown that branching is not confined to the spaces in $N$. Storriei. The following contradictions regarding allied forms are to be noted. In $N$. laxum, where the smaller tubes are excessively numerous, 'there are no spaces at all.' In $N$. Storriei, where there is no small-tube network, the spaces are particularly numerous and the branching well-marked. It appears to me, in consideration

1 Penhallow, loc cit., p. 43. 
Barber.-On Nematophycus Storriei, nov.sp. 337

of these difficulties, that it is admissible to seek for another explanation of the existence of spaces in the tissue. It is not probable that they have anything to do with reproduction, from their internal position and the absence of every trace of spore-like bodies; but it is quite in accordance with the structure of existing algae that the spaces might have some connection with the aeration of the plant. The branching of the tubes at these points would certainly not militate against such a function, in fact would rather be looked for. I do not, however, think it altogether impossible that these openings in the tissue had somewhat the significance of the medullary rays of higher plants, as suggested by Sir William Dawson. The interchanging of material between different parts of the plant-tissues would probably, even in an alga, be assisted by such channels. But if these openings have this character, we should expect to find the majority of included tubes running in the radial direction, and such is not the case.

It has occurred to me that the specimens described under the name of $N$. laxum might possibly be hapteres or clinging organs of $N$. Logani-although such a suggestion is perhaps premature, before having seen the fossil. The absence of air-spaces in such a part of the plant would not be surprising.

The specimens of $N$. Hicksii, so far described, have been in a very poor state of preservation. From the general character of the tissues and the mode of occurrence of the specimens in the Pen-y-glog quarry near Corwen-where I have carefully collected the fragments-I consider it possible that $N$. Hicksii and $N$. Storriei belong to one and the same species. I do not feel justified at present, however, in classing them together, and have preferred to introduce a new specific name to avoid possible future confusion. An examination of the single slide exhibiting structure, preserved in the Jermyn Street Museum, exhibits peculiarities which are not present in the slides of $N$. Storriei. There is certainly the appearance of transverse walls in the tubes, which here, as in N. Storrici, are of one kind. There is frequently a curious transverse sculpturing on the 
338 Barber.-On Nematophycus Storriei, nov. sp.

walls of the tubes, calling to mind scalariform thickening ${ }^{1}$; and curious triangular bodies are met with whose relations are obscure. Of these appearances I find a rough drawing in my note-book, which will suffice to attract attention to the details mentioned (see Fig. I 7).

St. John's, Antigua, W. I.

March I $4,189^{2}$.

${ }^{1}$ Mentioned by Etheridge, Q. J. G, S., Ang. I88I.

\section{EXPLANATION OF FIGURES IN PLATES XIX AND XX.}

Illustrating Mr. Barber's paper on Nematophycus Storriei.

Fig. I. Nematophycus Logani-longitudinal section from a photograph. $\times 45$.

Fig. 2. do. do. do. $\times 110$.

Fig. 3. do. transverse section do. $\times 90$.

Fig. 4. do. do. do. $\times 45$.

Fig. 5. N. Storriei do. do. $\times 45$.

Fig. 6. do. longitudinal section do. $\times 45$.

Fig. 7. do. transverse section from a drawing. $\times 160$.

Fig. 8. do. do. showing the fractured edge of a specimen, from a photograph. $\times 160$.

Fig. 9. N. Storriei, transverse section through a 'space,' from a drawing. $\times 160$

Fig. Io. do. longitudinal section through a 'space,' do. $\times 25^{\circ}$

Fig. II. do. do. showing branching of the tubes away from a 'space,' from a photograph.

Fig. I 2. $N$. Storriei, longitudinal section, from a drawing.

Fig. 13. do. transverse section of a single tube, from a drawing. $\times 800$.

Fig. I4. do. spore-like bodies, from drawings.

Fig. I5. N. Logani, sketch of a 'space' with large tube branching and small tubes branching.

Fig. 16. $N$. Logani, small tubes branching and divided by transverse walls, from drawings.

Fig. 17. N. Hicksii, rough drawings of the Jermyn St. Museum specimen. 


\section{Fig. 1.}

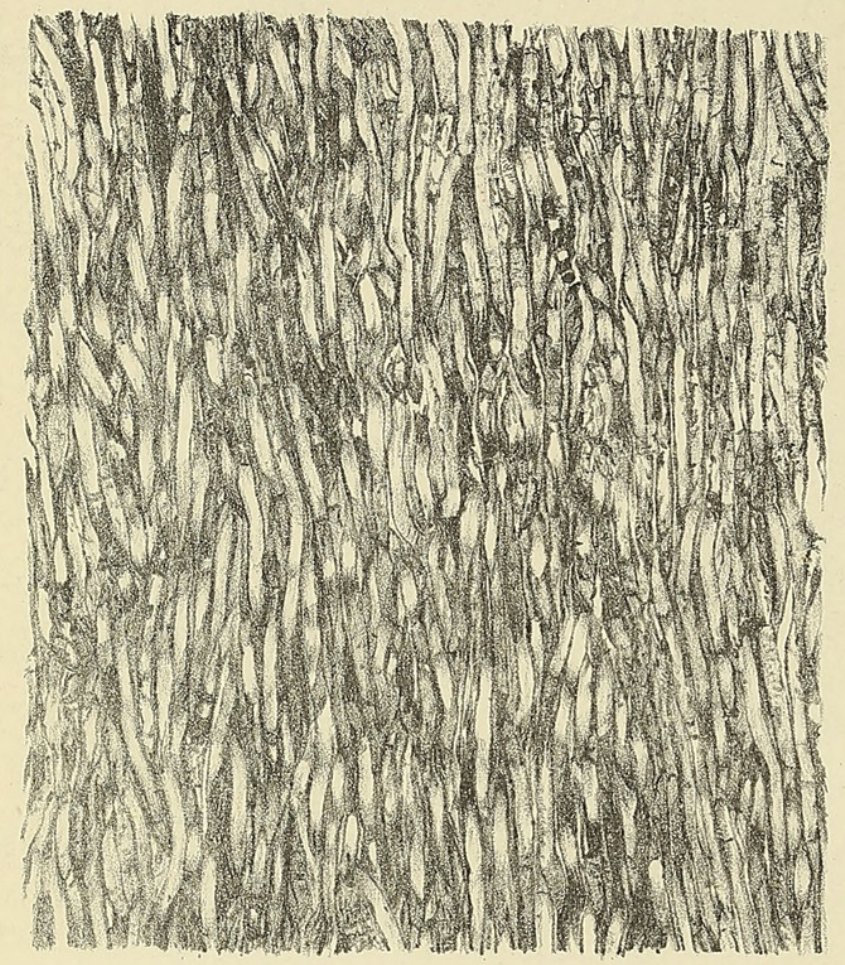

$$
\text { Fig. } 5 .
$$

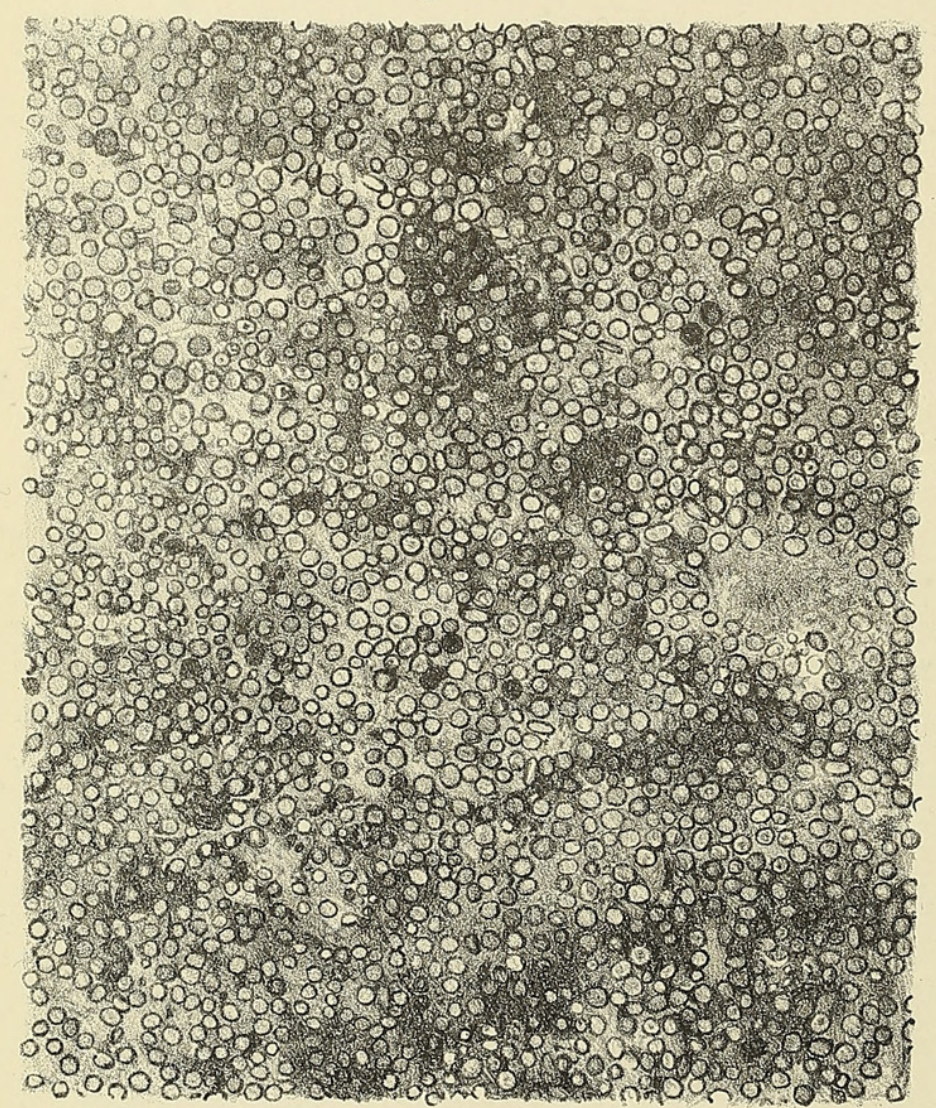

\section{Fig. 2.}

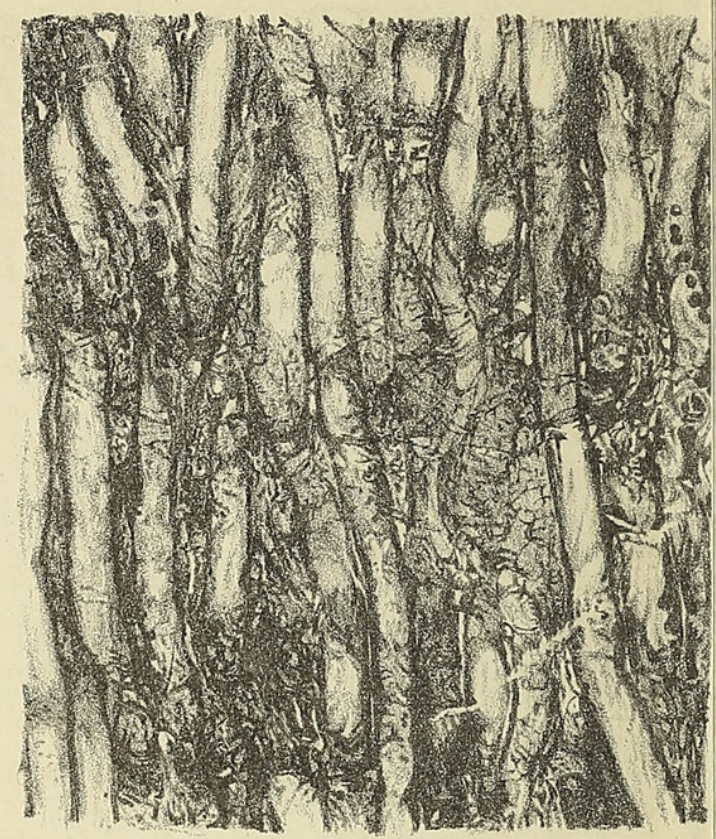

Fig. 6.

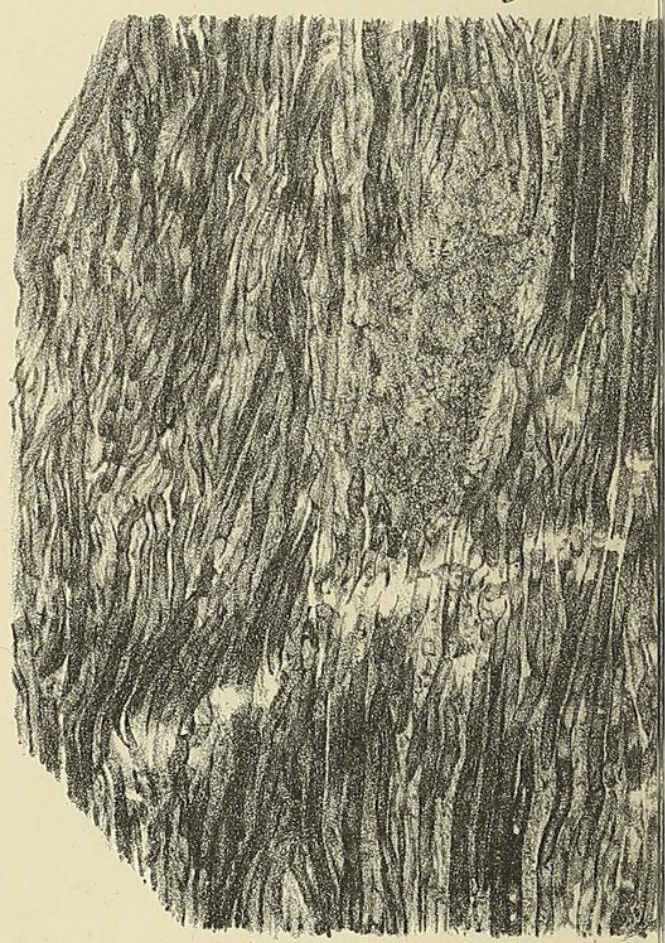

Fig. 8 .

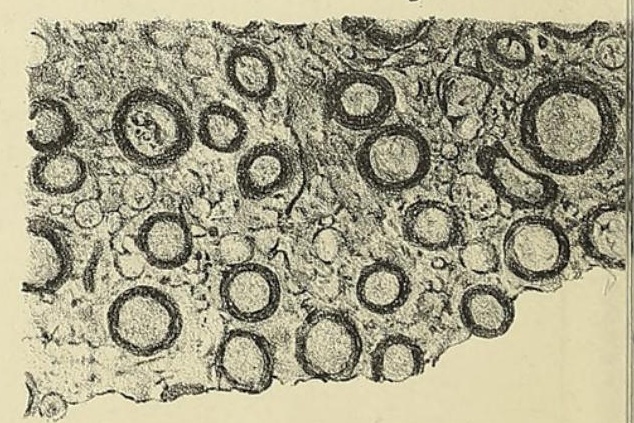



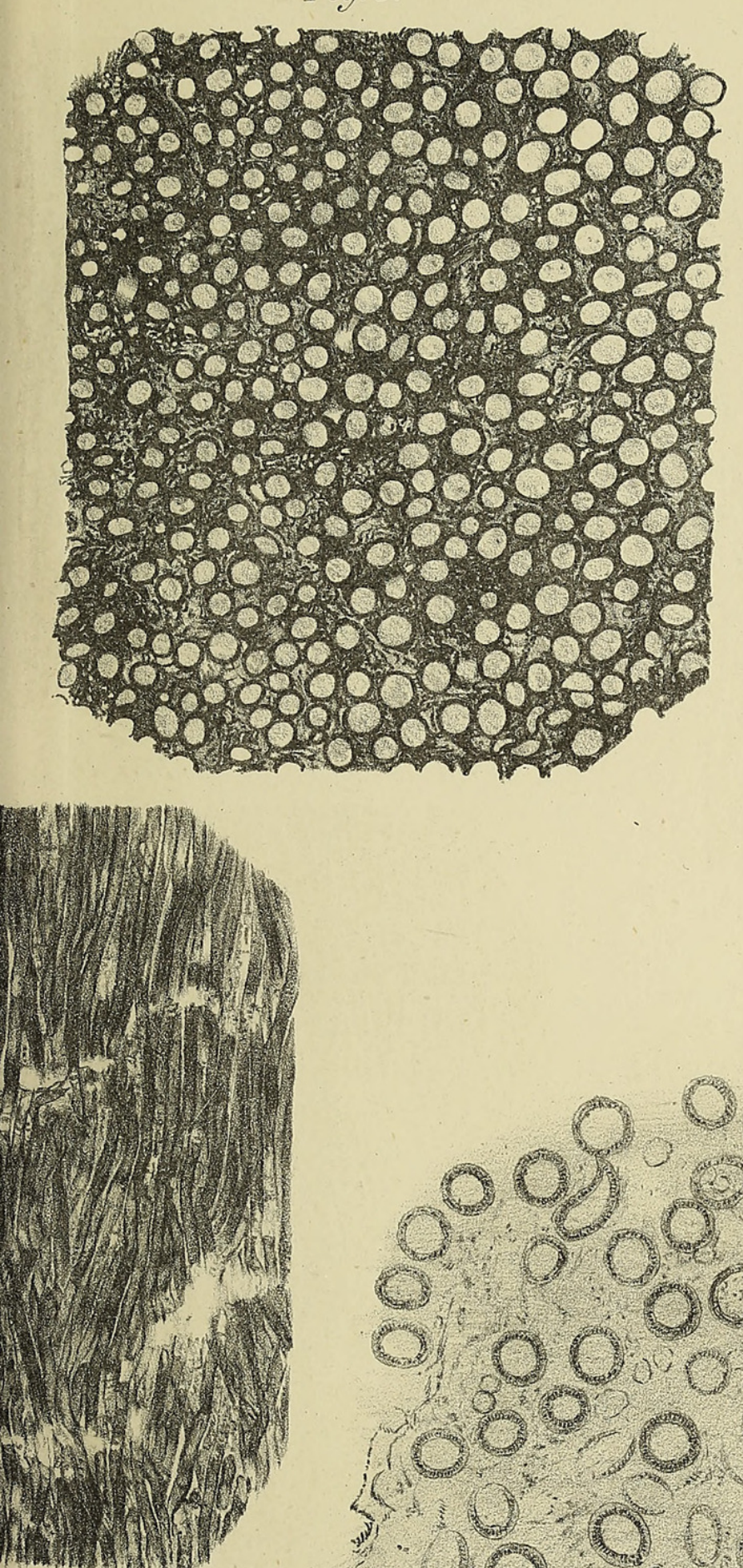

$$
\text { Fig. } 4 .
$$

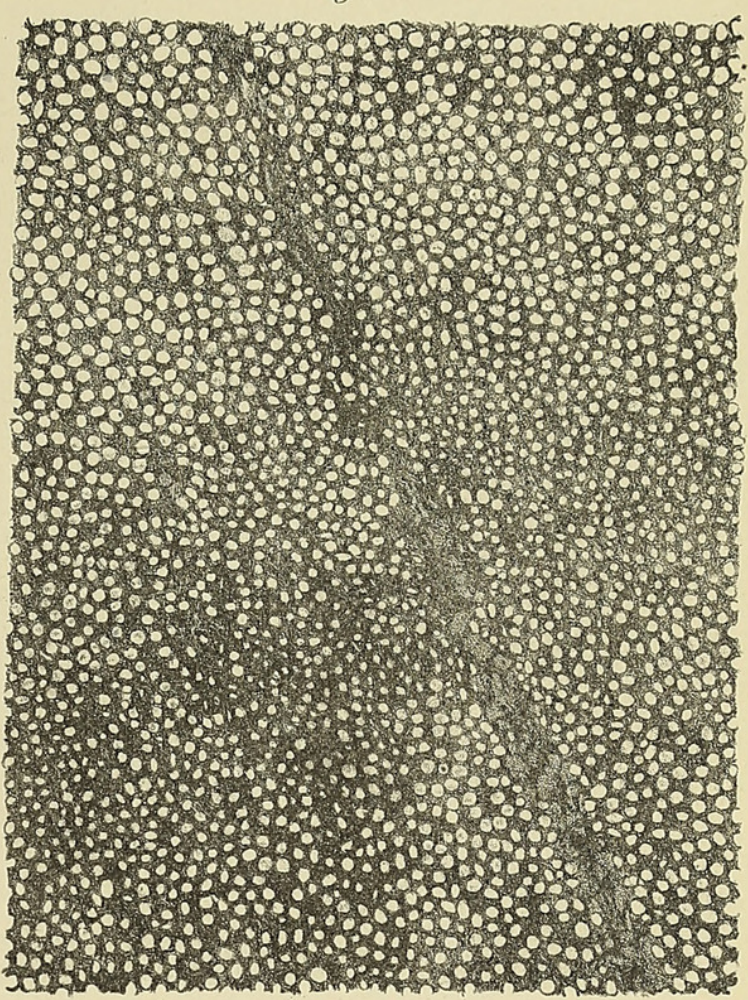

$$
\text { Fig. \%. }
$$

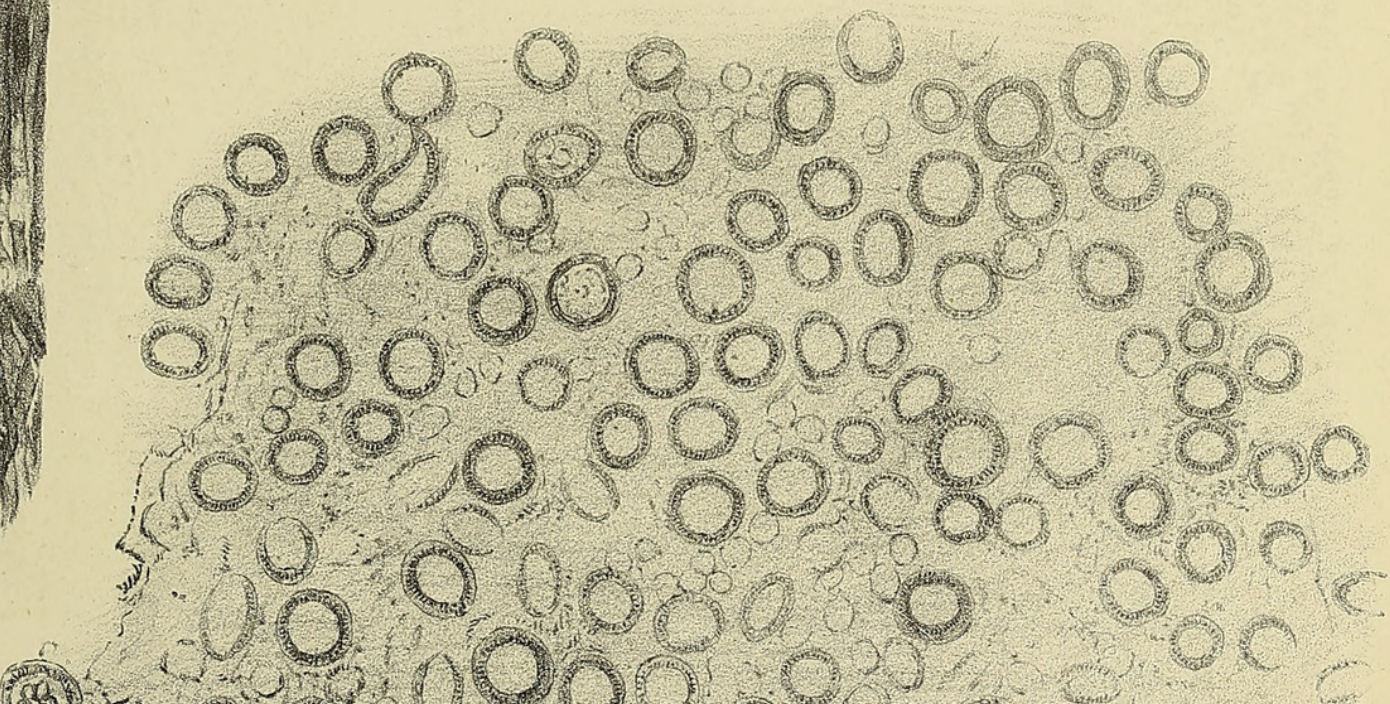

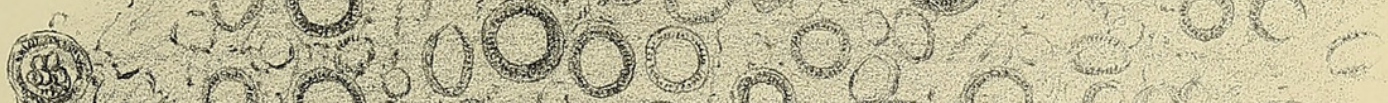

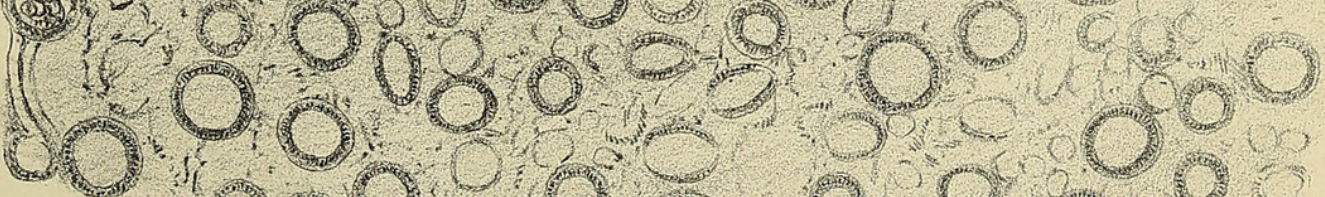

5.00 is 0.0 800 
Fig. 2.

Fig. 1.

A.M.

Fig. 5 .

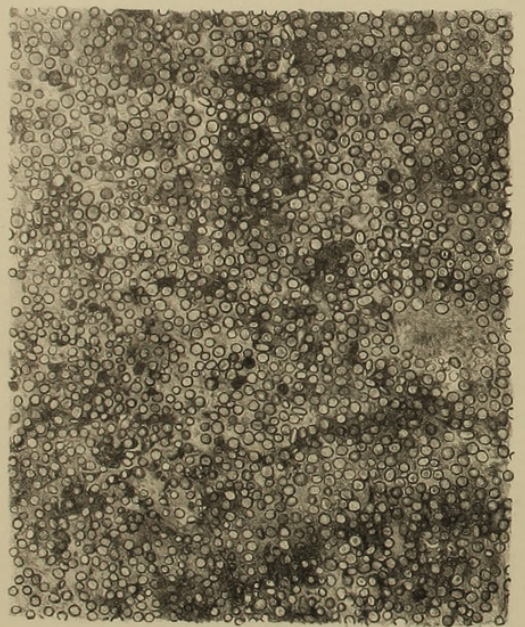

Fig. 3

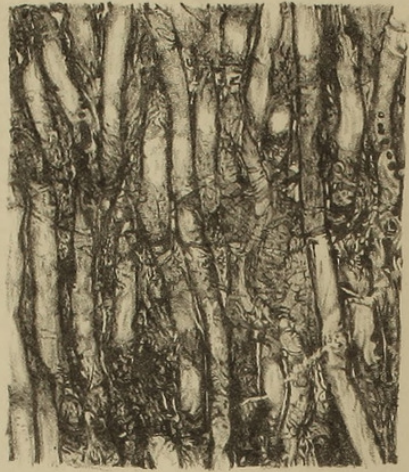

Fig. 6 .
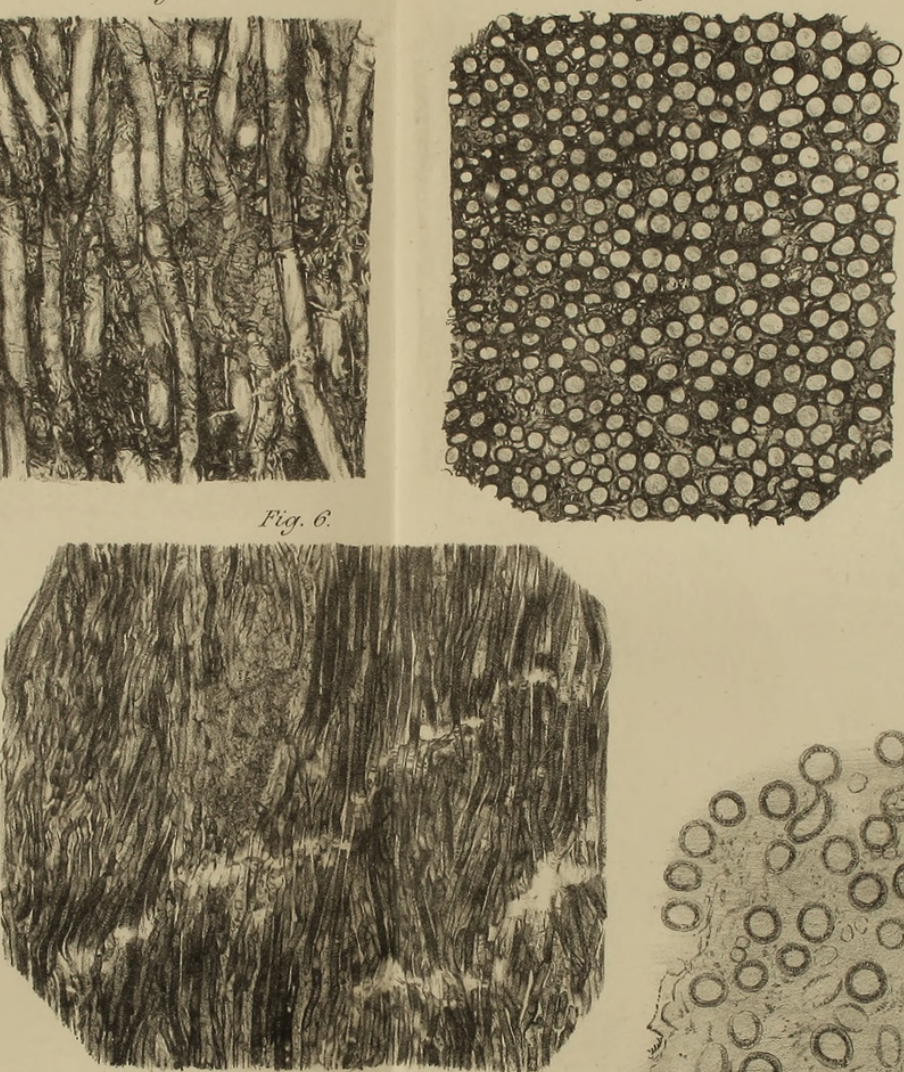

Fig. 8.

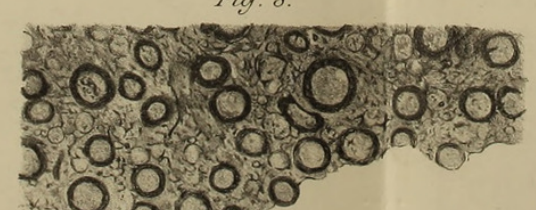

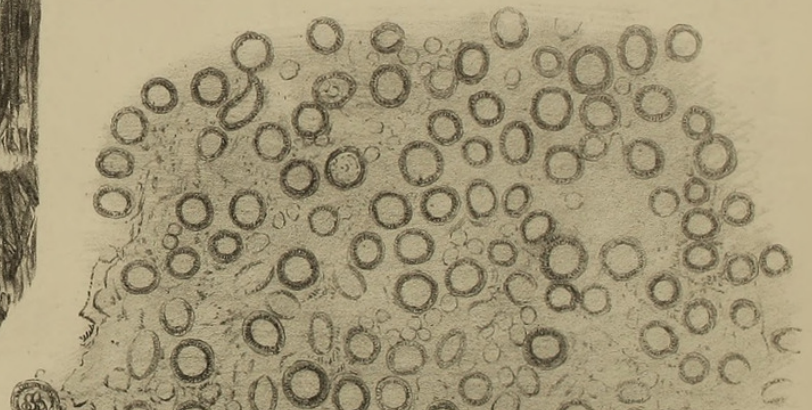

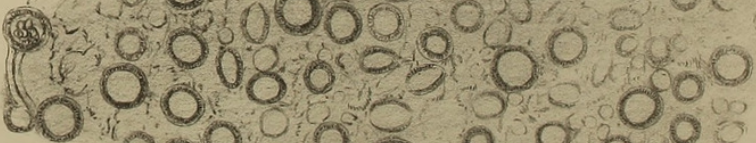
inomo

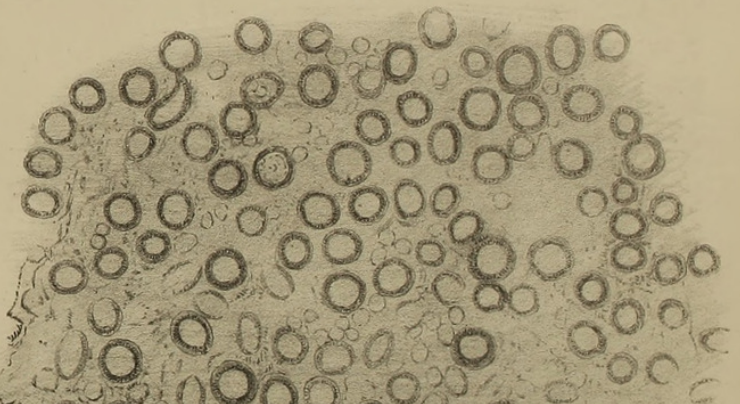

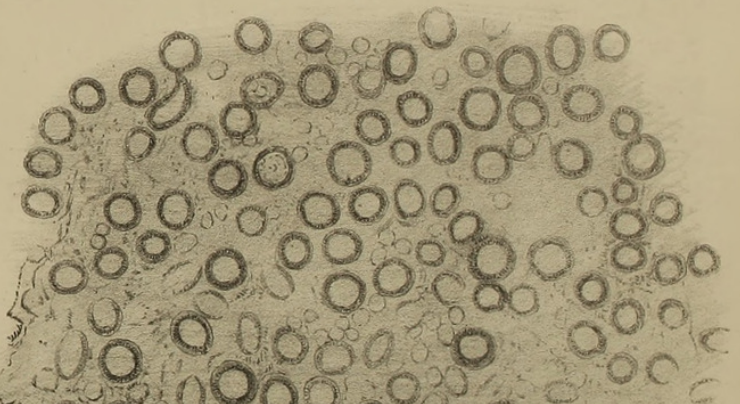

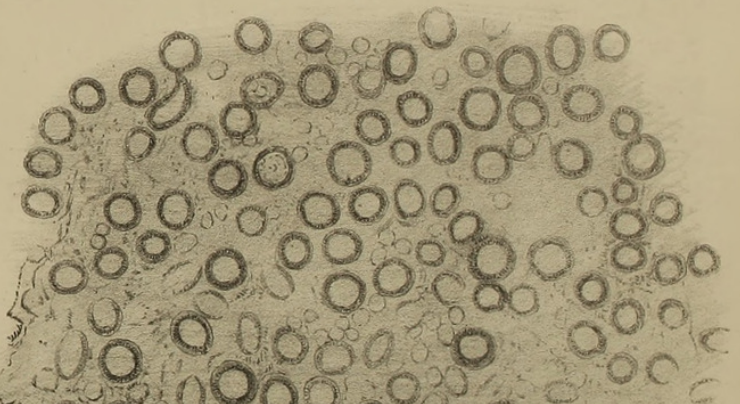

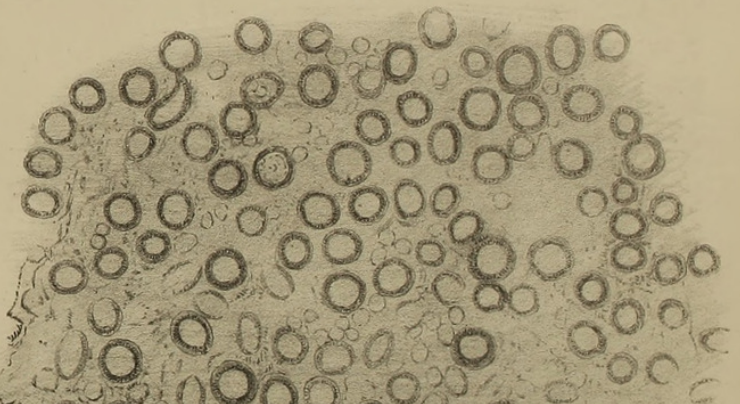

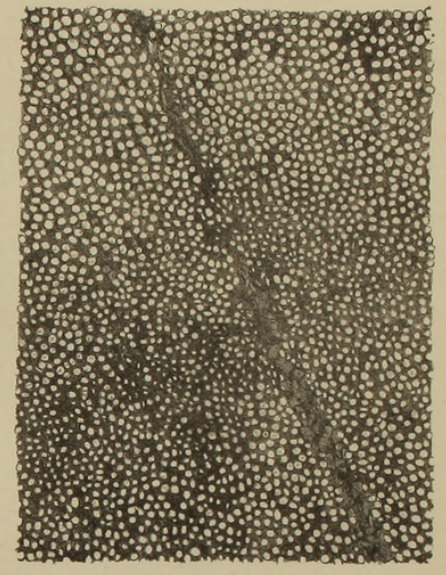
$.000 .080 .0 \%$ 


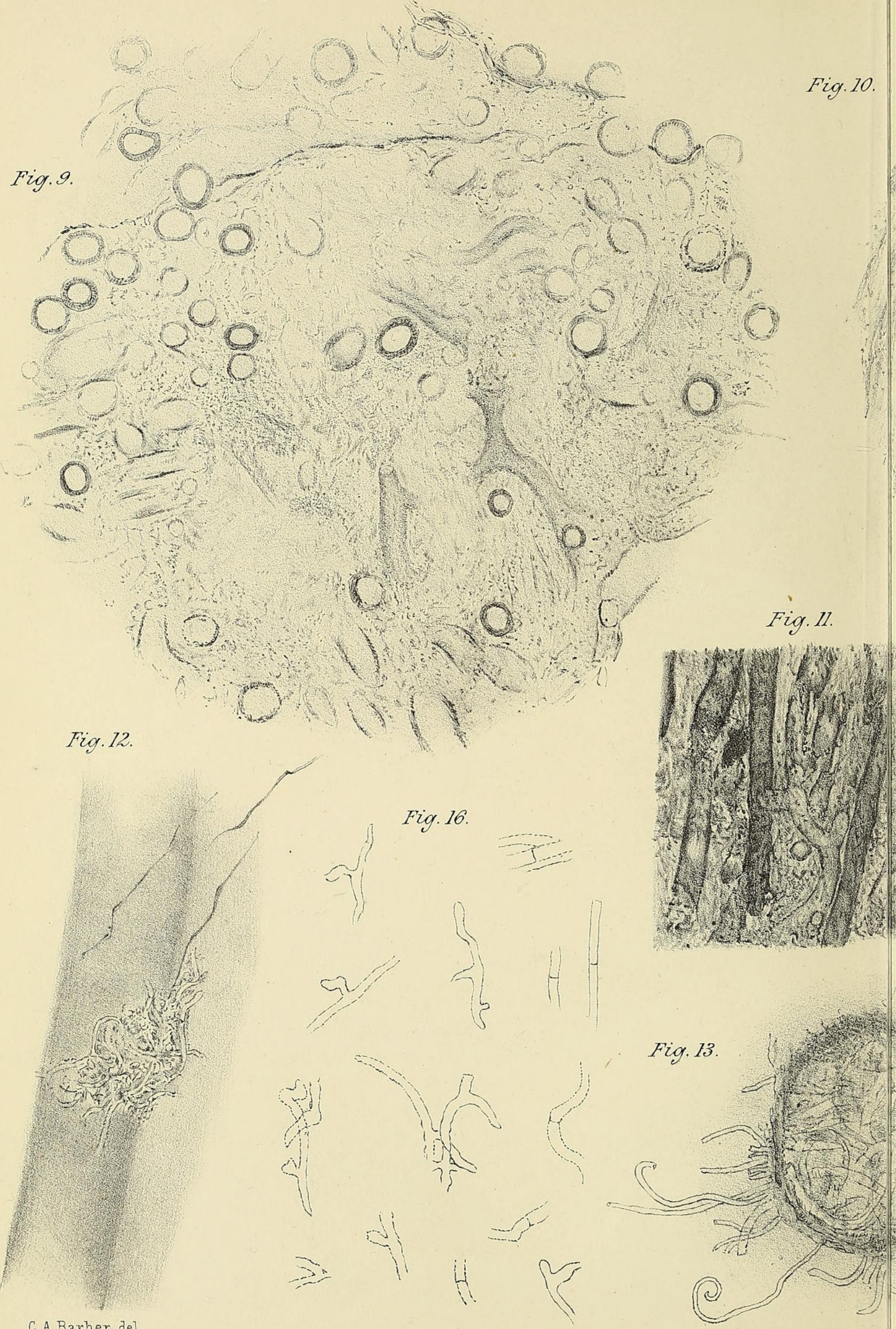

C.A.Barber del 
Vol.VI, PI. XX.

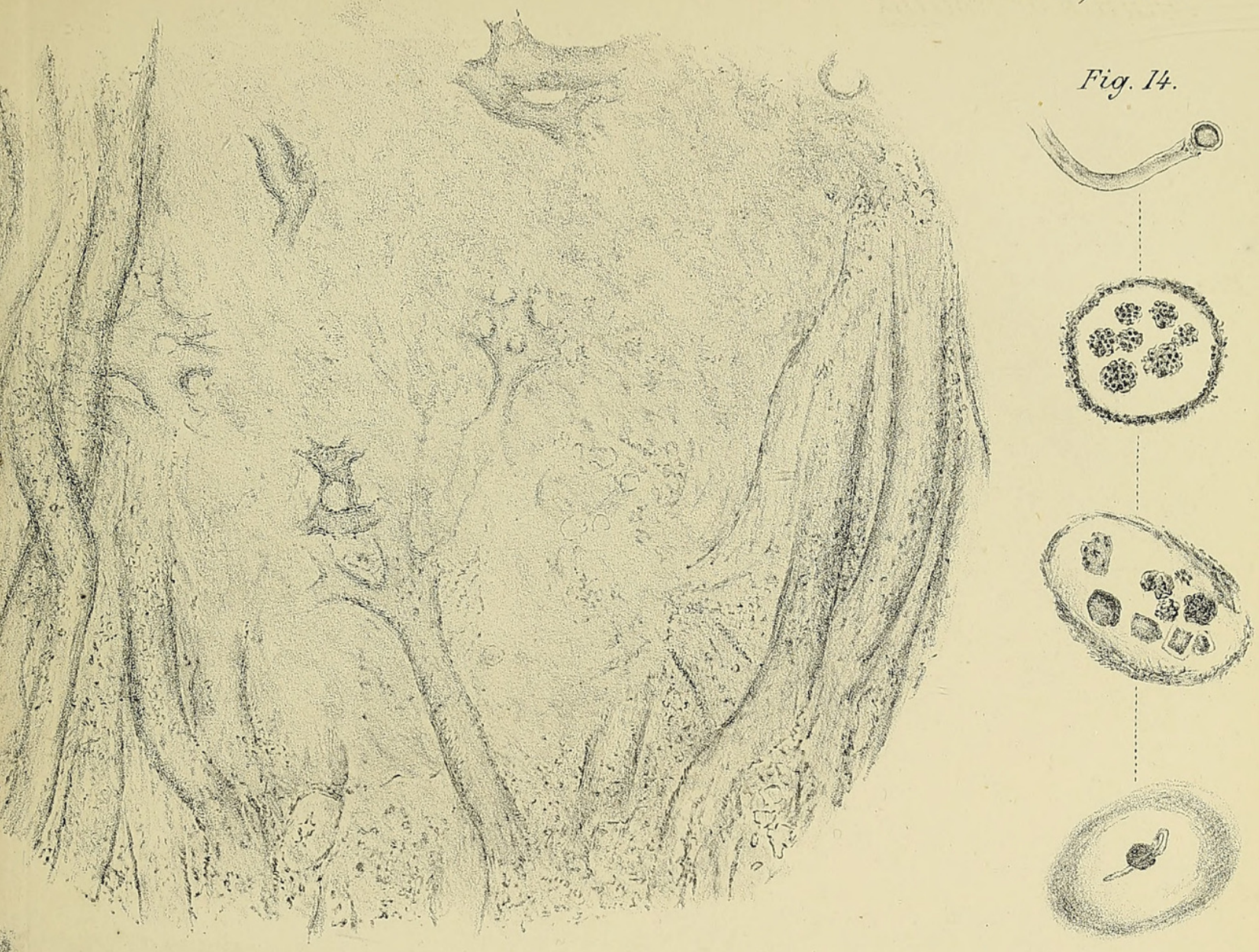

$\frac{11}{4}+4$
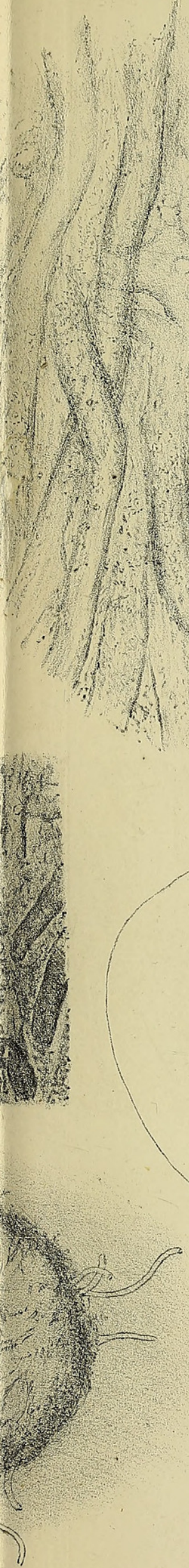

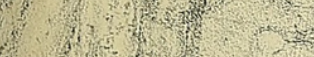

$(3+2), 6$

ine 3

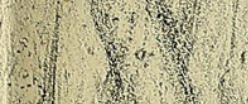

$\left(\frac{9}{3}\right)=9$

(4) dis

$8+2+1,4$

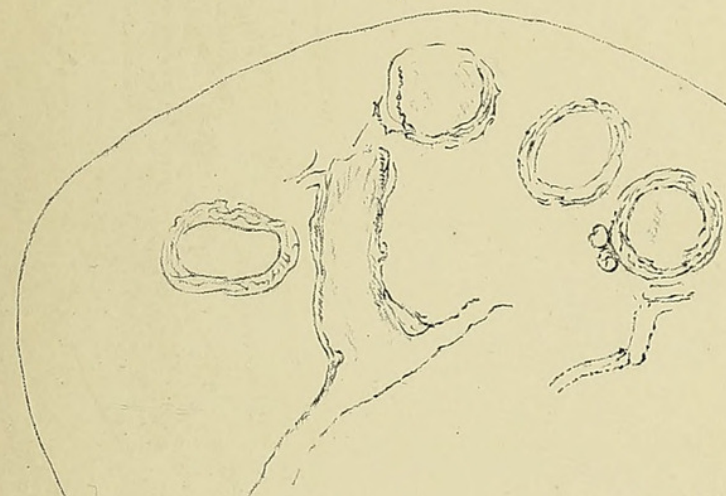

Fig. 15.
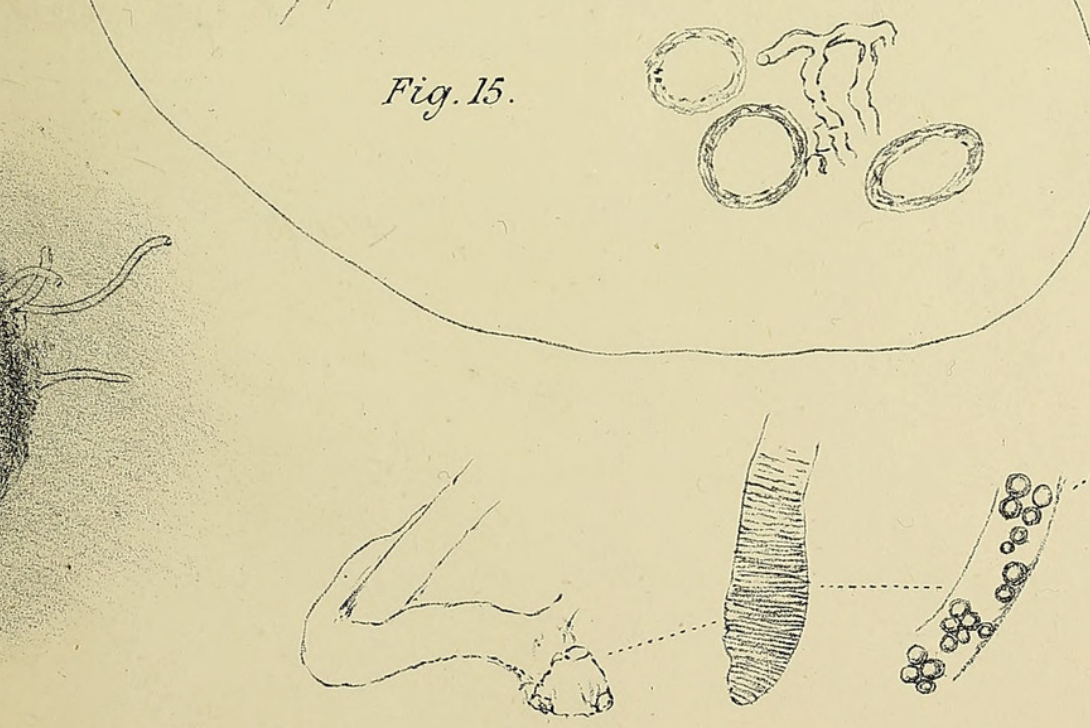

Fig. 1\%
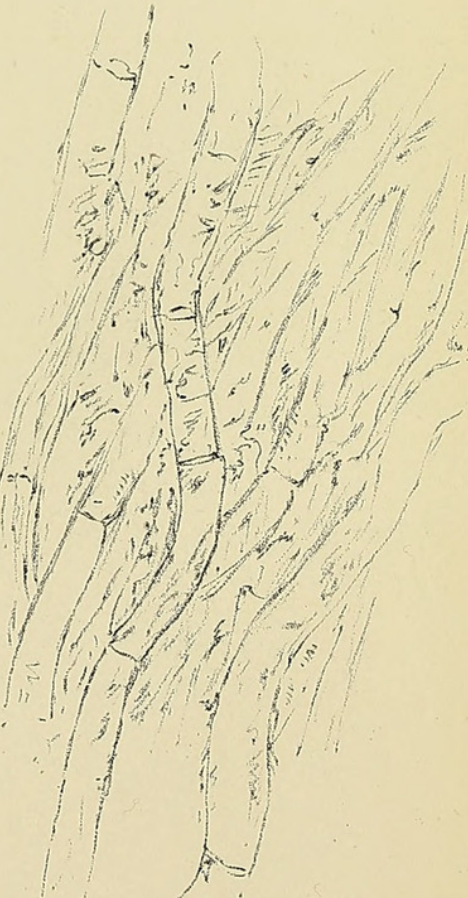

University Press, Oxford. 


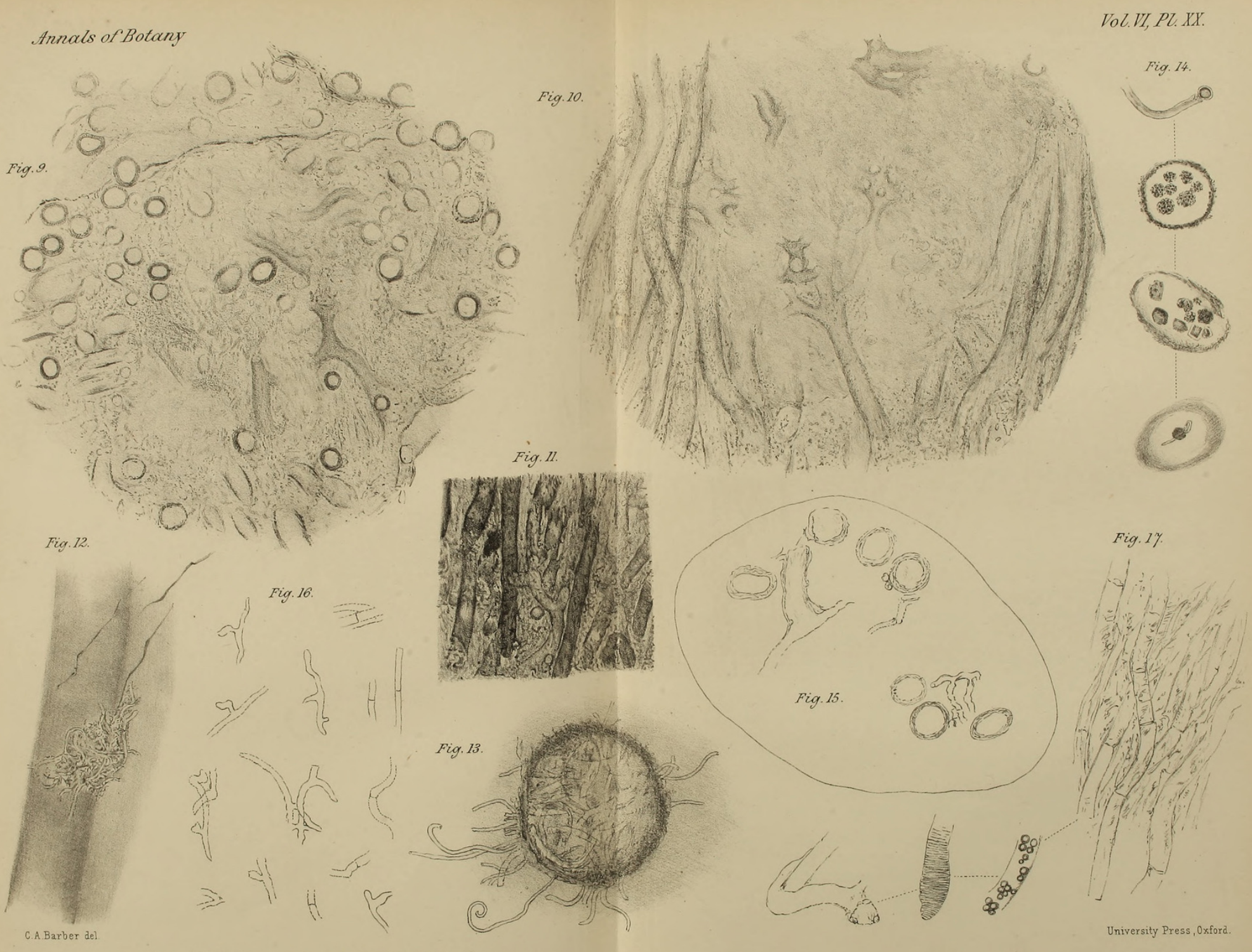

BARBER. - ON NEMATOPHYCUS. 


\section{$2 \mathrm{BHL}$ Biodiversity Heritage Library}

Barber, Charles Alfred. 1892. "Nematophycus storriei, nov. sp." Annals of botany 6, 329-338. https://doi.org/10.1093/oxfordjournals.aob.a090684.

View This Item Online: https://www.biodiversitylibrary.org/item/234968

DOI: https://doi.org/10.1093/oxfordjournals.aob.a090684

Permalink: https://www.biodiversitylibrary.org/partpdf/317716

\section{Holding Institution}

Smithsonian Libraries

\section{Sponsored by}

Biodiversity Heritage Library

\section{Copyright \& Reuse}

Copyright Status: Not in copyright. The BHL knows of no copyright restrictions on this item.

This document was created from content at the Biodiversity Heritage Library, the world's largest open access digital library for biodiversity literature and archives. Visit BHL at https://www.biodiversitylibrary.org. 